\section{Earnings quality, investment decisions, and financial constraint}

\author{
Flávio Leonel de Carvalho' \\ ${ }^{1}$ Federal University of São Carlos, Management and Technology \\ Center, Department of Administration, Sorocaba, Brazil \\ Aquiles Elie Guimarães Kalatzis² \\ ${ }^{2}$ University of São Paulo, School of Engineering of São Carlos, \\ Department of Production Engineering, São Carlos, Brazil
}

\begin{abstract}
Purpose - The purpose of this study was to investigate the relationship between accruals quality, financial constraint, and investment decisions and if earnings quality affects investment-cash flow sensitivities.

Design/methodology/approach - An analysis was conducted of a sample with 10,318 observations of 958 non-financial companies from seven different countries, covering 1992 to 2009. Then, the investment determinants were estimated using the Generalized Method of Moments (GMM).

Findings - Poor accruals quality was positively associated with investment rates for firms with overinvestment and negatively related to investment rates for firms with underinvestment. Additionally, the results indicate that accruals quality affects investment-cash flow sensitivities for firms in a situation of financial constraint; that is, poor accounting information quality can exacerbate the dependence of investment on free cash flow.
\end{abstract}

Originality/value - The results show that poor accruals quality could exacerbate the problems caused by the conflict of interest between decision-makers and shareholders or other stakeholders.

Keywords - Earnings quality. Investment decisions. Financial constraint.
Received on

$11 / 16 / 2016$

Approved on

$03 / 12 / 2018$

\section{Responsible editor:}

Prof. Dr. Eduardo Contani

Prof. Dr. João Maurício Gama

Boaventura

Evaluation process:

Double Blind Review

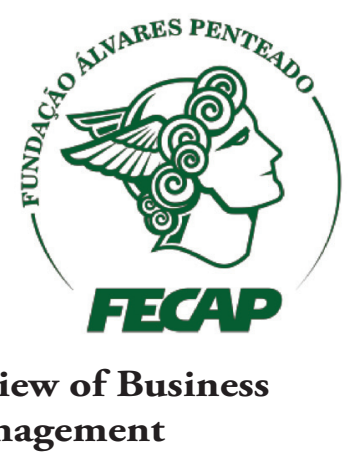

DOI: $10.7819 /$ rbgn.v0i0.3067 


\section{Introduction}

In order to inhibit earnings management, in 2002, the United States approved the Sarbanes-Oxley Act, which aimed to reinforce the importance of adopting corporate governance practices (Chan, Chou, Lin, \& Liu, 2016) and therefore provide greater reliability of reported financial information. Based on this initiative, legislators from different countries have sought ways to encourage the adoption of corporate governance practices (Sorensen \& Miller, 2017) that, in turn, can be understood as a set of mechanisms by which investors seek to ensure return on investment (Shleifer \& Vishny, 1997).

However, Lopes (2001) stated that the adoption of sophisticated and costly governance practices is needed when the accounting information system does not fulfill its role as an asymmetry reducer. Additionally, for Bushman, Chen, Engel, and Smith (2004), the adoption of a complex corporate governance structure derives from low-quality accounting. Given the above, it is possible to notice the existence of an intrinsic relationship between agency problems, attempts to reduce asymmetries, and the quality of financial reporting.

Quality accounting information is understood as the information relevant for decision-making, i.e., information that generates benefits that are greater than their costs, that are relevant and reliable, and that allow comparability between entities (Hendriksen \& Breda, 1999). Moreover, the quality of earnings has been used as a proxy to specify financial reporting quality, given that profit is a firm performance measurement that is often cited, analyzed, and discussed in the literature and in the financial community (Dechow \& Dichev, 2002; McNichols, 2002; Niu, 2006).

Apart from involving subjective aspects, profits are calculated and disclosed by managers and are therefore subject to influences by the various firm interests. According to Hribar, Melessa, Small, and Wilde (2017), the managers' beliefs about a company's future results are associated with accruals estimation errors. The subjective aspects inherent to the accrual basis of accounting, as well as the recognition decisions involving income or expenses and gains or losses, enable the manipulation of financial figures in favor of managers' objectives. The inherent subjectivity of the accounting recognition process is reflected in accounting adjustments, called accruals, consisting of the difference between the recognition of an economic event in firm results (accrual basis) and its actual impact on cash (Dechow \& Dichev, 2002; Dechow, Ge, \& Schrand, 2010).

Earnings should show the performance of a firm as accurately as possible. Thus, it is possible to assume, according to Carvalho, Kalatzis, and Albuquerque (2014), that the quality of accounting information can play an important role in decision-making. More accurate information allows for the better monitoring of managers' activities. As a consequence, this fidelity is expected to facilitate the process of controlling investment decisions.

An investment decision basically consists of the process of accepting or rejecting a particular investment project. Thus, it can be noted that, from a theoretical point of view, the decision is simple: projects for which the return is greater than the opportunity cost must be accepted, while others must be rejected. In real life, this process is not so easy, since the decision to accept or reject a project can be influenced by agents' interests in the decision-making process. Thus, accepting economically unviable projects or rejecting economically attractive projects can occur when the outcome of such deliberations offers benefits to decision makers, even when it causes losses to shareholders. In countries with weak law enforcement and low-quality financial information - which are common features of developing countries - the asymmetry problem and discretionary decisions taken by managers become even more relevant. However, few studies have focused on investigating this assumption (Verdi, 2006). 
Considering that earnings quality can reduce the asymmetry of information and that information asymmetry can enable inefficient investment decisions, the following question arises: does the quality of financial information influence the efficiency of investment decisions?

Another important aspect of investment decisions is the availability of external resources for investment. Firms for which access to debt can reduce investment opportunities can be considered financially constrained companies. In this situation, a company's investments will depend on the generation of internal cash. Thus, many studies have investigated the use of investment-cash flow sensitivity as a proxy for financial constraint. Firms for which investments are sensitive to internal cash flow are financially constrained.

However, the option of internally generated resources is not necessarily attributable to difficult access to external sources of capital; it could also be due to the decision makers' interests in avoiding publishing data that may increase the monitoring and control of their management. For Myers (1984) and Myers and Majluf (1984), there would be a hierarchy of preferences among the various sources of resources, and decision makers may prefer to use internal resources in investments because it would require a lower level of information reporting. Thus, the relationship between cash flow and investments may also be associated with the conflicts of interest present in the management process and the interest in maintaining the asymmetry of information between managers and investors (shareholders or creditors). In addition, an improvement in the transparency of financial information or the adoption of governance mechanisms would facilitate access to credit, provide lower funding costs, and enable the reduction of financial constraint problems (Botosan, 1997; Dechow et al., 2010; Francis, LaFond, Olsson, \& Schipper, 2005), and it is possible to suppose a negative relationship between low earnings quality and investment-cash flow sensitivity. Thus, one also wonders: does earnings quality affect investmentcash flow sensitivity?

It is therefore noted that the accounting flexibility derived from the accrual basis coupled with the divergent interests involved in a firm's management may stimulate discretionary behaviors (Kim, 2016) and thus influence investment decisions and investment-cash flow sensitivity. Based on the research problem, this study aims to investigate whether the quality of financial information influences the efficiency of corporate investment decisions in seven countries in Latin America - Argentina, Brazil, Chile, Colombia, Mexico, Peru, and Venezuela. Moreover, it aims to investigate whether earnings quality has an effect on investment-cash flow sensitivity.

This research investigates how the quality of financial information and the level of financial constraint impact a firm's investment decisions. We expect to verify the relationship between financial information and the efficiency of investment decisions. Moreover, we expect to analyze the theoretical assumption that investments for the group of companies classified as "firms with excess investment" have a negative relation with the quality of accounting information. Thus, as the accounting information quality improves, the volume of investments for companies investing in excess will decrease. In turn, we expect to test a theoretical hypothesis that the investments of firms investing in an inefficient way, that is, investing less than necessary (underinvesting), demonstrate a positive relation with the proxy for earnings quality. In addition, we expect the quality of financial information to affect investment-cash flow sensitivity. The theoretical basis for this last expectation is the argument that financially constrained firms that report information with quality and transparency will reduce the asymmetry of information between managers and creditors and could facilitate the acquisition of external resources. Additionally, the literature points out that a reduction in information asymmetry can impact the hierarchy 
of preferences for capital sources, since the maintenance of informational advantages, when using internal resources, will be minimized. Another contribution is the use of the Generalized Method of Moments (GMM) as a statistical tool for the estimation of significant investment variables, since it is uncommon to use this technique in this kind of study, especially when the relationship between investment decisions, earnings quality, and financial constraints is analyzed.

The study is structured in four sections, including this contextualization. The second section presents a brief theoretical framework discussing the determinants of corporate investments, the determinants of the quality of financial reporting, and the relationship between financial information quality, investment efficiency, and financial constraint. The third section presents the methodology employed. The fourth section analyzes the results and the main implications of the study, as well as their relationship with existing studies. Finally, we present considerations regarding the results obtained.

\section{Review of the Literature}

According to Branco (2006), from the perspective of agency theory, the main reason for reporting financial information is to alleviate the problem of information asymmetry by increasing shareholders', creditors', and others' access to information about a company. As access to information increases, the privileged position held by managers in relation to private information decreases. The author states that accounting is also a way to control managers' activities, as their behaviors change depending on the content of the disclosed information. Therefore, financial accounting plays an important role in facilitating the creation and fulfillment of contracts.

Given this background, studies have shown that the existence of information asymmetry and, consequently, of agency problems, which could be reduced by better-quality financial information, can affect asset values, the structure and cost of capital, and access to the credit market (Anderson, Mansi, \& Reeb, 2004; Bolton \& Freixas, 2000; Easley, Hvidkjaer, \& O’Hara, 2002; Easley \& O’Hara, 2004; Flannery, 1986; Francis, LaFond, Olsson, \& Schipper, 2004). In order to assess the quality of financial reporting, several variables (proxies) have been adopted, including variables that seek to measure the timeliness, relevance, and conservatism of this information. Although issues such as relevance, timeliness, and reliability are seen as key to the production process of quality financial reporting, there is no consensus regarding how they should be measured (Dechow et al., 2010).

We can observe the use of several measures of financial reporting quality in the literature, including the predictability and persistence of profits, which consist of the ability to predict future profits based on past profits (Penman \& Zhang, 2002); value relevance, which can be understood as the use of accounting figures as a basis for decision-making by investors (Ball \& Brown, 1968; Richardson, Sloan, Soliman, \& Irem, 2005); timeliness, which represents the speed at which financial information reaches its users (Bushman et al., 2004); income smoothness, which consists of the use of accounting adjustments to reduce profit variability (Demski, 1998; Kirschenheiter \& Melumad, 2002); and, finally, the quality of accruals, which measures the quality of financial reporting through the standard deviation difference between the observed and the estimated accounting adjustments (Aboody, Hughes, \& Liu, 2005; Dechow \& Dichev, 2002; Dechow et al., 2010; Francis et al., 2004; Francis, LaFond, Olsson, \& Schipper, 2005; Mcnichols, 2002).

For García-Teruel, Martínez-Solano, and Sánchez-Ballest (2009), the focus on the quality of accounting adjustments is justified, as they are related to the ability to predict future cash flows. Additionally, because the quality of accounting adjustments is one of the most important features 
for financial information users, its use as a proxy for quality seems relevant. According to Eng and Vichitsarawong (2017), the quality or the utility of accruals could be evaluated according to their ability to anticipate future earnings or future cash flows.

Various factors determine or influence the quality of financial information. According to Dechow et al. (2010), the operational characteristics of companies, their governance and internal control mechanisms, auditors' performance, incentives from the capital market, and financial practices adopted - besides factors external to the company - affect the quality of information.

In theory, efficient investment decisions relate to investments in projects that have a positive present net value and that provide maximum returns for the company and, hence, for shareholders (Biddle, Hilary, \& Verdi, 2009). For Richardson (2006), the level of investment can be estimated by the sales growth, debt, cash resources, size, profitability, and maturity of the firm. Thus, efficient investment decisions relate to the allocation of financial resources to be applied in projects (assets), considering their risk and returns ratio.

The monitoring and identification of profitable projects, as well as the opportunity to take corrective action when necessary, will depend on the existence and reporting of reliable information (Carvalho et al., 2014). In this sense, the quality of the financial information disclosed and made available to the market is essential to the process of monitoring investments and choosing projects in which to invest.

The economic and institutional implications of the quality of financial reporting are diverse, ranging from the appreciation or depreciation of shares to the impact on funding costs and investment decisions (Carvalho et al., 2014, Francis et al., 2004; Roosenboom, Goot, \& Mertens, 2003). However, given that markets are imperfect, it can be inferred that aspects such as asymmetric information, agency costs, bankruptcy risk, and restricted access to credit affect investments. In developing countries, where there is a lack of resources to realize investments, apart from the economic attractiveness of the projects, another important point to be considered is the availability of resources to implement them. Therefore, it is important to investigate the effect of financial constraints in investment decisions and their impact on earnings quality. Financial constraint refers to the situation when a firm presents difficulties in accessing external sources of financing (Whited, 1992).

Based on Durand (1952) and Modigliani and Miller (1958; 1963), much has been discussed regarding the importance of capital structure for firms' investment decisions. Initially, it was claimed that the degree of financial leverage was an irrelevant aspect in determining the value of companies (Durand, 1952; Modigliani \& Miller, 1958). Later, it was found that debt provides tax benefits that justify a higher share of external capital in organizations' financing structures (Modigliani \& Miller, 1963). Since then, several theories have emerged in an attempt to explain the factors that determine firms' capital structures.

However, in environments in which political and economic uncertainties are constant, resulting in capital markets that are demonstrably flawed, and with a corporate financial structure that is characterized by a high level of ownership concentration, access to credit plays a significant role when choosing funding sources.

Thus, many empirical studies (Almeida \& Campello, 2007; Bassetto \& Kalatzis, 2011; Hovakimian \& Titman, 2006) have sought to relate financial constraint to investment decisions by analyzing investment-cash flow sensitivity as a proxy for the existence of financial constraint. However, cash flow sensitivity as a measure of financial constraint has been criticized by Kaplan \& Zingales (1997) on the grounds that it may arise from factors such as profitability and future opportunity. Thus, the main problem identified in studies that seek to evaluate the impact of financial constraint in determining investments is the 
difficulty of finding a measure that appropriately captures the effects of financial constraint. As a consequence, a theoretical discussion about the relationship between investment-cash flow sensitivity and the level of financial constraint has been established. Nevertheless, few empirical studies that have analyzed the impact of financial constraint on investment decisions have considered information asymmetry and its influence on the preference for internal resources. In this context, in addition to influencing the choice of funding sources, information asymmetry may affect the appropriateness of investment decisions.

Vogt (1994) investigated the reasons for the relationship between cash flow and investments and found a significant relationship between unproductive investments and excess cash flow in companies with dispersed capital control and low dividend distribution levels. In environments with poor legal structures (low enforcement), administrators may make investments even if they do not add value to the firm. Thus, the availability of internally generated funds may, in some situations, have more of an impact investment decisions than the projects' actual economic viability. Vogt (1994) addressed the hypothesis that information asymmetry affects investment decisions and that the preference for internal resources is due to the lower sensitivity to information on internal resources, in addition to their lower transaction costs.

Thus, investment-cash flow sensitivity is partly related to companies' degree of asymmetry, as when there is information asymmetry between managers and shareholders, available cash flows may be used for inadequate investments. Therefore, asymmetry reduction mechanisms are expected to reduce investment-cash flow sensitivity, for as the level of information asymmetry decreases, the investment monitoring process and, therefore, the investment decisions improve. Thus, it is expected that mechanisms to reduce asymmetry, by facilitating access to information, can reduce the sensitivity of investments to cash flow and, consequently, improve decisions on the investments made by executives (the company).

Carvalho et al. (2014) studied the relationship between the quality of financial information and the likelihood of efficient investment decisions. The authors classified firms according to efficiency in investment decisions and, using a proxy for earnings quality, analyzed the impact of this variable on the probability of efficient or inefficient decisions. The study indicates that companies with low earnings quality are less likely to make efficient investments and are more likely to fail to make investments, even when they are economically recommended. In this context, we expect the quality of financial information to contribute to reducing the level of asymmetry, which, in turn, will reduce investment-cash flow sensitivity.

Another point to note is that the choice of financing investments with internal resources may be related to the importance attributed to the level of information asymmetry. In this sense, the pecking order theory proposed by Myers and Majluf (1984) and Myers (1984) deserves mention. According to this theory, the type of financing chosen is related to the sensitivity of the sources of financing to information (Albanez \& Valle, 2009). From this point of view, initially the option would be to finance with internally generated resources because it would require a lower level of information. Next, the preference would be for debt and, finally, to finance through the issuance of shares.

Thus, financial constraints, information asymmetry, investment-cash flow sensitivity, and the quality of financial information are topics with an intrinsic relationship, and therefore, better financial information is expected to reduce information asymmetry, decrease investment-cash flow sensitivity, and enable efficient investment decisions. 


\section{Methodology}

This study was conducted using a database that was built with information obtained using the Economática ${ }^{\oplus}$ software and that covered the $1992-$ 2009 period, creating an unbalanced panel of
10,318 observations of 958 non-financial public companies from seven different Latin American countries, as seen in Table 1. The database used in this research, as well the construction of the variables, is the same as that built and used in Carvalho et al. (2014).

Table 1

\section{Observations by economic sector and country}

\begin{tabular}{|c|c|c|c|c|c|}
\hline Economic sector & Obs. & Percentage & Country & Obs. & Percentage \\
\hline Agriculture and fishing & 730 & $7.08 \%$ & Argentina & 872 & $8.45 \%$ \\
\hline Food and drinks & 1,382 & $13.39 \%$ & Brazil & 3,928 & $38.07 \%$ \\
\hline Trade & 992 & $9.61 \%$ & Chile & 2,048 & $19.85 \%$ \\
\hline Construction & 524 & $5.08 \%$ & Colombia & 281 & $2.72 \%$ \\
\hline Electro and electronics & 113 & $1.10 \%$ & Mexico & 1,511 & $14.64 \%$ \\
\hline Electricity & 1,237 & $11.99 \%$ & Peru & 1,480 & $14.34 \%$ \\
\hline Non-metallic minerals & 545 & $5.28 \%$ & Venezuela & 198 & $1.92 \%$ \\
\hline Mining & 591 & $5.73 \%$ & & & \\
\hline Oil and gas & 278 & $2.69 \%$ & & & \\
\hline Chemistry & 891 & $8.64 \%$ & & & \\
\hline Siderurgy and metallurgy & 1,013 & $9.82 \%$ & & & \\
\hline Telecommunications & 659 & $6.39 \%$ & & & \\
\hline Textile & 824 & $7.99 \%$ & & & \\
\hline Transportation services & 297 & $2.88 \%$ & & & \\
\hline Vehicles and spare parts & 242 & $2.35 \%$ & & & \\
\hline Total & 10,318 & $100.00 \%$ & & 10,318 & $100.00 \%$ \\
\hline
\end{tabular}

Observations from financial companies were excluded from the sample because they are controlled by national agencies and regulated by specific laws and therefore could not be compared with companies from other economic sectors. Observations containing measurement errors and companies with negative shareholder equity were excluded from the sample because they could prejudice the statistical analysis. The statistical package Stata 11 (StataCorp, 2009) was used to obtain the estimates.

In order to meet the objectives of this study - namely, to investigate the relationship between the quality of financial information, financial constraints, and investment decisions in Latin America - it was necessary to build a proxy and sort the firms according to their earnings quality, efficiency in investment decisions, and financial constraint.

\section{I Earnings quality}

Accounting information quality $(A Q)$ was measured using the methodology adopted by Core, Guay, and Verdi (2008) based on the proposal from Sloan (1996). Thus, $A Q$ was determined using the standard deviation between the total observed accruals (Equation 1) and the total estimated accruals (Equation 2). 


$$
T A_{j, t}=\left(\Delta A C_{j, t}-\Delta D i s p_{j, t}\right)-\left(\Delta P C_{j, t}-\Delta F i n C P_{j, t}\right)-\Delta D e p_{j, t}
$$

Where TA is total accruals; $t$ is the year; $j$ is the company; $\triangle C A$ is the change in current assets; $\triangle$ Avail is the variation in cash (cash and cash equivalents); $\triangle C L$ is the change in current liabilities; $\triangle F i n S T$ is the change in short-term financing; and Dep represents the depreciation, amortization, and depletion; all the variables presented in Equation 1 were divided by average total assets between years $\mathrm{t}$ and $\mathrm{t}-1$.

$$
\begin{gathered}
\widehat{T A}_{i j, t}=\beta_{0(i, t)}+\beta_{1(i, t)} F C O_{i j, t-1}+\beta_{2(i, t)} F C O_{i j, t}+\beta_{3(i, t)} F C O_{i j, t+1}+\beta_{4(i, t)}\left(\Delta V_{i j, t}-\Delta C \operatorname{Rec}_{i j, t}\right) \\
+\beta_{5(i, t)} \operatorname{Imob} i j, t+\varepsilon_{(i, t)}
\end{gathered}
$$

Where $i$ is the economic sector analyzed; $\widehat{T A}$ is the total accruals estimated; $O C F$ is the operating cash flow measured as (Ebit-TA), where Ebit is the operating profit and $T A$ is calculated in Equation 1; $\Delta S$ is the change in net operating revenues; $\triangle \mathrm{ARec}$ is the variation in accounts receivable; $F A$ is fixed assets; and $\varepsilon$ refers to the error. All variables in the model presented in Equation 2 were divided by the average total assets.
Finally, the accruals quality was obtained by the standard deviation of the residuals of the model estimated in Equation 2 between years $\mathrm{t}-4$ and $\mathrm{t}$, that is, for the last five years of each company of the sample. Thus, it was possible to measure the standard deviation of the accounting adjustments, represented by $A Q$, for only the companies in which there were historical data of the residuals for that period. Therefore,

$$
A Q=\sqrt{\frac{1}{(n-1)} \sum_{t-4}^{t}(\mu-\bar{\mu})}
$$

Where $A Q$ is the proxy employed as a measure of earnings quality and is based on the sample standard deviation of the accounting adjustments resulting from the difference between the cash basis and accrual basis of each company between the years $t-4$ and $t ; \mu$ is the residual of the model estimated using Equation $2 ; \bar{\mu}$ is the mean of the residual of the model estimated using
Equation 2 for the last 5 years or for the period between $\mathrm{t}$ and $\mathrm{t}-4$; and $n$ refers to the number of observations used to calculate the sample standard deviation, which, in Equation 3 above, is 5 observations.

The $A Q$ variable, apart from representing low earnings quality, enabled the companies to be sorted into 3 groups, as shown in Figure 1. 


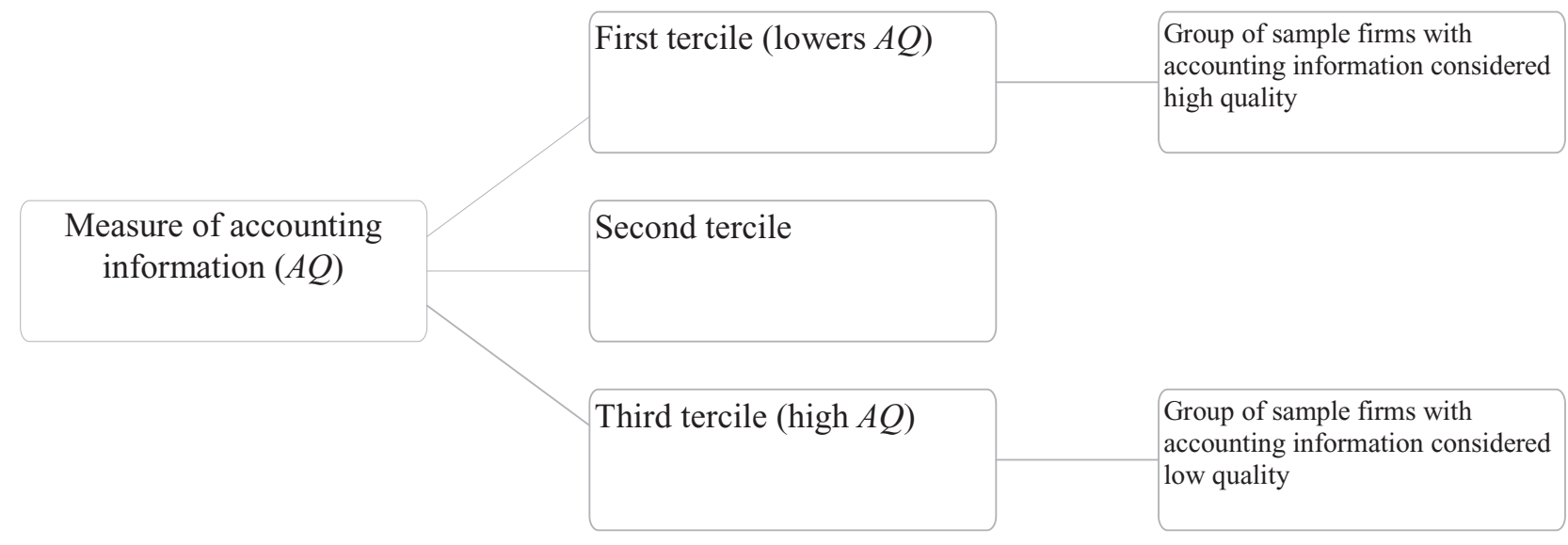

Figure 1. Grouping of firms according to the quality of financial information

\subsection{Financial constraint}

The degree of financial constraint was assessed by the $K Z$ index, as proposed by Lamont, Polk, and Saá-Requejo (2001), and based on the results from Kaplan and Zingales (1997). Although there are different ways to evaluate financial constraints, the present study opted for the proposal of Lamont, Polk, and Saá-Requejo (2001), which has been widely used in the literature. It is suggested, however, that future studies use other instruments to measure financial constraint. The calculation of the $\mathrm{KZ}$ index is constructed according to Equation 4.

$$
K Z_{j, t}=-\left(1,0019 * \frac{F C_{j, t}}{K_{j, t-1}}\right)+\left(0,2826 * Q_{j, t}\right)+\left(3,1291 * \frac{D_{j, t}}{A T_{j, t}}\right)-\left(39,3678 * \frac{\text { Div }_{j, t}}{K_{j, t-1}}\right)-\left(1,3147 * \frac{\text { Caixa }_{j, t}}{K_{j, t-1}}\right)
$$

Where $K Z$ refers to the financial constraint of the firm; $K$ is the capital stock (fixed assets); $C F$ is the operating cash flow, measured using the operating profit (Ebit) and adding depreciation, amortization, and depletion; $Q$ is an estimate of Tobin's $Q$, calculated as follows: $(M V+D) / A T S$, where $M V$ is the market value of the company stock, $D$ is the total liabilities, and ATS is the total assets; Div is the amount of dividends distributed; and Cash is the total amount of cash or cash equivalents.
By using the $\mathrm{KZ}$ index, it was possible to sort the samples into financially constrained and non-financially constrained firms. The criterion used to distinguish the two groups was the division of firms into terciles, as shown in Figure 3, with the first tercile being composed of the companies considered to be not financially constrained and the third tercile by the companies considered to be financially constrained.

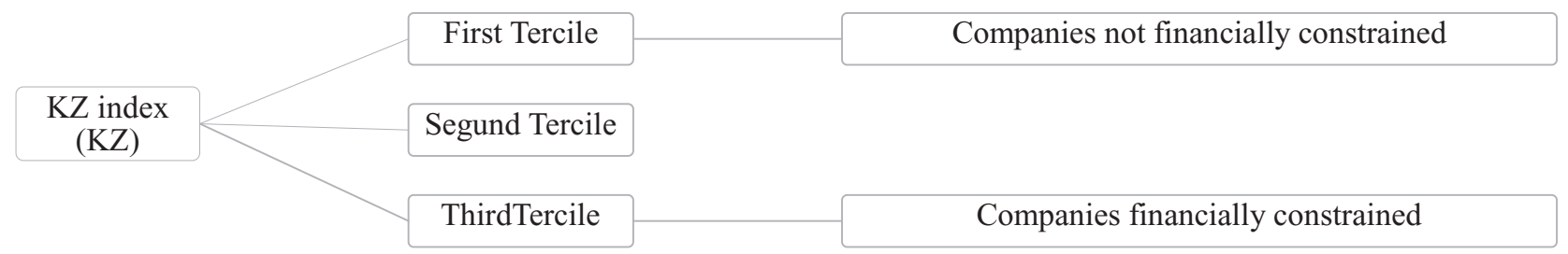

Figure 2. Grouping of companies according to their degree of financial constraint 


\subsection{Efficiency in investment decisions}

In order to sort the firms according to their efficiency in investment decisions, this study employed an adaptation of the model proposed by Richardson (2006), noting the amendments made by Verdi (2006), Li and Wang (2010), Core, Guay, and Verdi (2008), and Verdi (2006) and used by Carvalho, Kalatzis, and Albuquerque (2014). With this methodology, investment efficiency is measured as the difference between the estimated investments (Equation 5) and the volume of investments observed. Both a lack of investments (negative values and values far from zero) and an excess (positive values and values far from zero) are called inefficient investment decisions. The estimate of the required volume of investments was obtained using multiple linear regression, estimated individually every year for each sector of the economy, as shown in the formulation below (Equation 5). In this model, it is observed that the investment rate is determined by lagged explanatory variables, which is justified by the lag time between the growth of sales and the availability of resources and their impact on investments.

$$
\operatorname{In} v_{j, t}=\gamma_{0(i, t)}+\gamma_{1(i, t)} \Delta V_{j, t-1}+\gamma_{2(i, t)} \operatorname{Alav}_{j, t-1}+\gamma_{3(i, t)} \operatorname{Caixa}_{j, t-1}+\gamma_{4(i, t)} \operatorname{Tam}_{j, t-1}+\gamma_{5(i, t)} \operatorname{Re} t_{j, t-1}+\vartheta_{j, t}
$$

Where Inv is the percentage change in fixed assets; $i$ the sector of the economy; $\Delta S$ refers to the percentage change in sales revenue; Lev is the company's leverage ratio, obtained by dividing long-term debt by total assets; Cash is the available cash (and cash equivalents) divided by the average total assets; Size refers to size, measured by the natural logarithm of total assets; Ret is the annual return of shares; and $\vartheta$ is the model error. The residual of the model estimated by Equation 5, represented by $\Psi$ and given below, enabled the companies to be sorted into three distinct groups according to their investment decisions (Figure 2).

$$
\Psi_{j, t}=\operatorname{In} v_{j, t}-\operatorname{In} v_{j, t}
$$

Where $I n v$ is the investment rate; $I \hat{n} v$ is the estimated volume of investments; and $\Psi$ is the residual of model 5 , related to the difference between investments effectively made by each firm and the volume of investments deemed necessary by the model estimated by Equation 5. Thus, based on the residual of the model, we could identify differences and make the necessary groupings, as shown in Figure 3.

\section{Efficient investment decisions: the residuals of the model are near zero}

\begin{tabular}{l|l|l|}
\hline $\begin{array}{l}\text { Investment } \\
\text { decisions }\end{array}$ & $\begin{array}{ll}\text { Inefficient investment } \\
\text { decisions: residuals far } \\
\text { from zero }\end{array}$ & $\begin{array}{l}\text { Overinvestment: the residuals of the model are far from } \\
\text { zero and positive }\end{array}$ \\
\hline
\end{tabular}

Figure 3. Grouping of firms according to efficiency in investment decisions 


\subsection{Investment model}

In order to analyze the determinants of investments, a modified version of the investment accelerator model was used. This model originally attempted to predict the behavior of investments through changes in the firm's product. It is based on the premise that there exists an association between change in output or change in consumption and investment, a relationship known as product capital. According to Kammler \& Alves (2005), the consumption variation can be obtained through a change in sales, and capital investment can be represented by fixed assets. This model was selected because of its simplicity and, according to Kammler and Alves (2005), because it allows for investment estimation changes.

\subsection{Investment model: grouping the firms according to earnings quality}

For firms grouped according to earnings quality (Figure 1), a modified version of the investment accelerator model was estimated using the Generalized Method of Moments (GMM), as shown in Equation 7.

$$
\begin{aligned}
& \left(\frac{I}{K_{t-1}}\right)_{j, t}=\alpha+\beta_{1}\left(\frac{I}{K_{t-1}}\right)_{j, t-1}+\beta_{2}\left(\frac{I}{K_{t-1}}\right)_{j, t-1}^{2}+\beta_{3}(b K Z)_{j, t}+\beta_{4}\left(\frac{F C}{K_{t-1}}\right)_{j, t}+\beta_{5}\left(\frac{V}{K_{t-1}}\right)_{j, t}+\beta_{6}\left(\frac{D}{K_{t-1}}\right)_{j, t}+ \\
& \beta_{7}(\mathrm{Tam})_{j, t}+\beta_{8}(\Delta V)_{j, t}+\beta_{9}(\Delta V)_{j, t-1}+\beta_{10}\left(\frac{F C}{K_{t-1}} * K Z\right)_{j, t}+\beta_{11}\left(\frac{F C}{K_{t-1}} * R O E\right)_{j, t}+\beta_{12}\left(\frac{F C}{K_{t-1}} * \operatorname{Tam}\right)_{j, t}+\varepsilon_{j, t}
\end{aligned}
$$

Where $I$ is the company's investment rate, measured as the change in capital stock; $K$ is the capital stock, measured by assets; and $b K Z$ refers to an indicator variable for financial constraint, which is 1 if the company is constrained and 0 if it is not financially constrained. The grouping of firms according to their level of financial constraint was performed in accordance with the suggestion of Lamont, Polk, and Saá-Requejo (2001), as shown in Figure 3; CF refers to cash flow, defined as the sum of amortization, depletion, and depreciation added to net income; $S$ is sales, obtained through the net operating revenues; $D$ refers to debt, measured as the current liabilities plus the non-current liabilities; Size is the size of the firm, measured as the natural logarithm of total assets; $\Delta S$ is the sales growth; $K Z$ is a continuous variable representing the degree of financial constraint; and $R O E$ is the return on equity. The multiplication of the variables $K Z, R O E$, and Size by cash flow refers to the interaction variable, whose objective was to measure the effect of each of these characteristics (financial constraints, profitability, and company size) on investment sensitivity to cash flow.

\subsection{Investment model: grouping the firms according to financial constraint}

For firms grouped according to their level of financial constraint (Figure 2), with the objective of analyzing whether accruals quality impacts the investment decisions of financially constrained Latin American companies, a modified version of the investment accelerator model was estimated using the GMM, as shown in Equation 8.

$$
\begin{aligned}
& \left(\frac{I}{K_{t-1}}\right)_{j, t}=\alpha+\beta_{1}\left(\frac{I}{K_{t-1}}\right)_{j, t-1}+\beta_{2}\left(\frac{I}{K_{t-1}}\right)_{j, t-1}^{2}+\beta_{3}(A Q)_{j, t-1}+\beta_{4}\left(\frac{F C}{K_{t-1}}\right)_{j, t}+\beta_{5}\left(\frac{V}{K_{t-1}}\right)_{j, t}+\beta_{6}\left(\frac{D}{K_{t-1}}\right)_{j, t}+ \\
& \beta_{7}(\mathrm{Tam})_{j, t}+\beta_{8}(\Delta V)_{j, t}+\beta_{9}(\Delta V)_{j, t-1}+\beta_{10}\left(\frac{F C}{K_{t-1}} * A Q\right)_{j, t}+\beta_{11}\left(\frac{F C}{K_{t-1}} * R O E\right)_{j, t}++\beta_{12}\left(\frac{F C}{K_{t-1}} * T a m\right)_{j, t}+\varepsilon_{j, t}
\end{aligned}
$$


Where $t$ and $j$ refer to the year and the firm, respectively; $I$ is the company's investment rate, measured by the change in capital stock; $K$ is the capital stock, measured by fixed assets; $A Q$ is a continuous variable inversely related to earnings quality; $C F$ refers to cash flow, defined as the sum of amortization, depletion, and depreciation added to net income; $S$ is sales, obtained by net operating revenues; $D$ refers to debt, measured as the current liabilities plus the non-current liabilities; Size is the size of the firm, measured as the natural logarithm of total assets; $\triangle S$ is the sales growth; and $R O E$ is the return on equity.
The multiplication of the variables $K Z, R O E$, and Size by cash flow refers to the interaction variable, whose objective is to measure the effect of each of these characteristics (financial constraint, profitability, and company size) on investmentcash flow sensitivity.

\subsection{Investment model: grouping the firms according to efficiency in investment decisions}

For firms grouped according to their efficiency in investment decisions (Figure 1), the following model was estimated:

$$
\begin{aligned}
& \left(\frac{I}{K_{t-1}}\right)_{j, t}=\alpha+\beta_{1}\left(\frac{I}{K_{t-1}}\right)_{j, t-1}+\beta_{2}\left(\frac{I}{K_{t-1}}\right)_{j, t-1}^{2}+\beta_{3}(A Q)_{j, t-1}+\beta_{4}(b K)_{j, t}+\beta_{5}\left(\frac{F C}{K_{t-1}}\right)_{j, t}+\beta_{6}\left(\frac{V}{K_{t-1}}\right)_{j, t}+\beta_{7}\left(\frac{D}{K_{t-1}}\right)_{j, t}+\beta_{8}(\operatorname{Tam})_{j, t}+ \\
& +\beta_{9}(\Delta V)_{j, t}+\beta_{10}(\Delta V)_{j, t-1}+\beta_{11}\left(\frac{F C}{K_{t-1}} * A Q\right)_{j, t}+\beta_{12}\left(\frac{F C}{K_{t-1}} * K Z\right)_{j, t}+\beta_{13}\left(\frac{F C}{K_{t-1}} * R O E\right)_{j, t}+\beta_{14}\left(\frac{F C}{K_{t-1}} * T a m\right)_{j, t}+\varepsilon_{j, t}
\end{aligned}
$$

Where $I$ is the company's investment rate, measured as the change in capital stock; and $K$ is the capital stock, measured by fixed assets. The multiplication of the variables $A Q, K Z, R O E$, and Size by cash flow refers to the interaction variable.

The models represented by Equations (7), (8), and (9) show the following characteristics: (i) they involve sectional and temporal information on the companies, i.e., they consist of unbalanced panel data containing a large number of observations for a short period of time; (ii) the models have a single dependent variable with dynamic behavior - the "investment relative to capital stock" in the aforementioned equations. Because the volume of investments made in a year is influenced by investments in previous years, the inclusion of the lagged dependent variable as an explanatory variable may cause endogeneity problems; (iii) the independent variables of cash flow, sales, and debt relative to capital stock may be correlated with their past values and errors; (iv) each company has specific characteristics, such as the technical capacity of their managers, which, in theory, will not change over time; and (v) the variables feature heteroscedasticity and autocorrelation.

The above characteristics, listed by Roodman (2009), justify the use of the Generalized Method of Moments (GMM) suggested by Arellano and Bond (1991). The investment models can be estimated using the GMM-Dif or GMM-System methodologies. Both are suitable to the model estimated, i.e., with small panel data that take into account the existence of independent variables that are not strictly exogenous. According to Arellano and Bover (1995) and Blundell and Bond (1998), the GMM-System method may be more suitable than GMM-Dif, because the instruments (level-lagged variables) may be weak if the series are highly persistent. However, with the GMM-System method, there may be a considerable increase in instruments, which influence the estimates. Therefore, the present study selected the GMMDif method, since the series used do not seem to have strong persistence. Given that GMM-Dif is not usually employed in the Brazilian empirical literature, we believe that its use in this study is an important contribution. 
Therefore, this study used the second lag of the level-dependent variable as an instrument. Since the variables $\left(C F / K_{t-1}\right)_{j t},\left(S / K_{t-1}\right)_{j t}$ and $\left(D / K_{t-1}\right)$ ${ }_{j t}$ may be correlated with past periods, they were assumed to be predetermined, i.e., variables that may be correlated with past mistakes but not with future ones. The GMM estimator was obtained in two steps in order to ensure homoscedasticity in the residuals (Arellano \& Bond, 1991).

The existing heterogeneity among the different companies in the sample was considered when sorting the models according to earnings quality (Equation 7), degree of financial constraint (Equation 8), and efficiency in investment decisions (firms with effective decisions, overinvestment, and underinvestment) (Equation 9). This classification allowed the sample to become more homogeneous.
The Sargan test was employed to test the validity of the instruments used, and its results are presented in the results tables.

\section{Results and analysis}

In order to analyze the determinants of investment, the companies were grouped according to the quality of their financial information, their degree of financial constraint, and their efficiency in investment decisions. The relationship between investment decisions, earnings quality, and financial constraint was then analyzed.

As can be seen in Table 2, the correlation between the variables is low (lower than 0.5), which leads us to conclude that there are no potential problems of multicollinearity.

Table 2

\section{Correlation matrix}

\begin{tabular}{|c|c|c|c|c|c|c|c|c|c|}
\hline & $\left(\mathbf{I} / \mathbf{K}_{t-1}\right)$ & $\left(\mathrm{CF} / \mathrm{K}_{\mathrm{t}-1}\right)$ & $\left(\mathbf{S} / \mathbf{K}_{\mathrm{t}-1}\right)$ & $\left(\mathrm{D} / \mathrm{K}_{\mathrm{t}-1}\right)$ & $(\Delta S)$ & (Size) & (AQ) & (KZ) & (ROE) \\
\hline$\left(\mathrm{I} / \mathrm{K}_{\mathrm{t}-1}\right)$ & 1 & & & & & & & & \\
\hline$\left(\mathrm{CF} / \mathrm{K}_{\mathrm{t}-1}\right)$ & 0.1697 & 1 & & & & & & & \\
\hline$\left(\mathrm{S} / \mathrm{K}_{\mathrm{t}-1}\right)$ & 0.1951 & 0.3397 & 1 & & & & & & \\
\hline$\left(\mathrm{D} / \mathrm{K}_{\mathrm{t}-1}\right)$ & 0.2489 & 0.1576 & 0.5471 & 1 & & & & & \\
\hline$(\Delta S)$ & 0.4741 & 0.2688 & 0.1821 & 0.1339 & 1 & & & & \\
\hline (Size) & 0.1295 & 0.0996 & -0.1149 & 0.0475 & 0.1554 & 1 & & & \\
\hline (AQ) & -0.0005 & 0.0185 & 0.0891 & 0.0768 & -0.028 & -0.1996 & 1 & & \\
\hline$(\mathrm{KZ})$ & -0.0608 & -0.4887 & -0.2733 & -0.0667 & -0.0323 & 0.0936 & 0.0258 & 1 & \\
\hline (ROE) & 0.1234 & 0.5296 & 0.1136 & -0.0014 & 0.2102 & 0.1429 & -0.049 & -0.243 & 1 \\
\hline
\end{tabular}

where $I$ is the company's investment rate, measured as the change in capital stock; $K$ is the capital stock, measured by assets; $C F$ refers to cash flow, defined as the sum of amortization, depletion, and depreciation added to net income; $S$ is sales, obtained through the net operating revenues; $D$ refers to debt, measured as the current liabilities plus the non-current liabilities; $\Delta S$ is the sales growth; Size is the size of the firm, measured as the natural logarithm of total assets; $A Q$ is the proxy employed to measure earnings quality and evaluated based on the standard deviation of accounting adjustments, that is, the difference between cash and accruals for each company between years $\mathrm{t}-4$ and $\mathrm{t}$, according to Equation 3 ; $\mathrm{KZ}$ is a continuous variable representing the degree of financial constraint, according to Equation 4; and ROE is the return on equity.

Table 3 shows descriptive statistics for each variable for the companies grouped according to high and low levels of earnings quality, financial constraints and no financial constraints, and firms with investment decisions considered to be efficient and firms with overinvestment and underinvestment.
The Sargan test was employed to test the validity of the instruments used. As the null hypothesis is not rejected, we can conclude that the instruments used are valid. The Arellano and Bond test (1991), whose objective is to analyze the existence of correlation with the residual, was also used. The result, which rejects the null hypothesis 
of second-order autocorrelation, indicates the absence of autocorrelation between the error and the dependent variable.

It is possible to note in Table 4 that investments by firms from all groups are negatively correlated with the lagged dependent variable $\left(\left(I / K_{t-1}\right)_{j, t-1}\right)$, as well as with the square lagged dependent variable $\left.\left(\left(I / K_{t-1}\right)^{2}\right)_{j, t-1}\right)$, i.e., the ratio of investments involves a nonlinear dynamic relationship, and the volume of investments in a given year will affect investments in the following year. The use of a lagged dependent variable as an explanatory variable is justified by the need to provide a dynamic character to the model. In addition, a squared dependent variable is used because of the need to represent the nonlinearity of the investment model.

Table 3.

\section{Descriptive statistics}

\begin{tabular}{|c|c|c|c|c|c|c|c|c|}
\hline & \multirow{2}{*}{ Total sample } & \multicolumn{2}{|c|}{ Accruals quality } & \multicolumn{2}{|c|}{ Financial constraint } & \multicolumn{3}{|c|}{ Investment decision } \\
\hline & & High & Low & No & Yes & Efficient & Over & Under \\
\hline \multicolumn{9}{|c|}{$\left(\mathbf{I} / \mathbf{K}_{t-1}\right)$} \\
\hline Mean & 0.0950 & 0.0548 & 0.0610 & 0.1325 & 0.0654 & 0.0453 & 0.3707 & -0.0641 \\
\hline SD & 0.4105 & 0.2772 & 0.4130 & 0.4642 & 0.4161 & 0.2007 & 0.5545 & 0.2592 \\
\hline Min. & -3.6024 & -1.0000 & -3.6024 & -1.0000 & -3.6024 & -1.0000 & -0.9926 & -3.6024 \\
\hline Max. & 3.8974 & 3.8974 & 3.8385 & 3.8974 & 3.7744 & 1.8843 & 3.8974 & 2.0325 \\
\hline \multicolumn{9}{|c|}{$\left(\mathrm{CF} / \mathrm{K}_{\mathrm{t}-1}\right)$} \\
\hline Mean & 0.1915 & 0.1762 & 0.1916 & 0.4052 & 0.0351 & 0.1705 & 0.2407 & 0.1644 \\
\hline SD & 0.5614 & 0.3943 & 0.6509 & 0.7430 & 0.5177 & 0.4005 & 0.6103 & 0.5314 \\
\hline Min. & -4.7683 & -3.7013 & -4.1763 & -4.7683 & -4.6471 & -2.9138 & -4.1763 & -4.7683 \\
\hline Max. & 4.9986 & 4.1877 & 4.5323 & 4.9986 & 4.6645 & 4.5629 & 4.9986 & 4.8047 \\
\hline \multicolumn{9}{|c|}{$\left(\mathbf{S} / \mathbf{K}_{\mathrm{t}-1}\right)$} \\
\hline Mean & 2.4135 & 1.9942 & 2.7824 & 3.1247 & 2.1761 & 2.1589 & 2.6992 & 2.3067 \\
\hline SD & 2.8173 & 2.2956 & 3.0565 & 3.4638 & 2.6774 & 2.4492 & 2.9715 & 2.7879 \\
\hline Min. & 0.0000 & 0.0000 & 0.0000 & 0.0000 & 0.0000 & 0.0000 & 0.0000 & 0.0000 \\
\hline Max. & 19.9981 & 18.4233 & 19.5142 & 19.9981 & 19.7033 & 19.9981 & 19.7033 & 19.7345 \\
\hline \multicolumn{9}{|c|}{$\left(\mathbf{D} / \mathrm{K}_{\mathrm{t}-1}\right)$} \\
\hline Mean & 1.6659 & 1.4627 & 1.9477 & 1.8024 & 1.9680 & 1.4328 & 1.9920 & 1.5418 \\
\hline SD & 1.9969 & 1.8992 & 2.1796 & 2.6486 & 1.9141 & 1.5544 & 2.1584 & 1.9452 \\
\hline Min. & 0.0000 & 0.0000 & 0.0000 & 0.0000 & 0.0000 & 0.0111 & 0.0000 & 0.0000 \\
\hline Max. & 19.7521 & 19.3803 & 19.7521 & 19.7521 & 19.3803 & 18.0537 & 19.0000 & 19.3803 \\
\hline \multicolumn{9}{|l|}{$(\Delta \mathbf{S})$} \\
\hline Mean & 0.1313 & 0.0980 & 0.0867 & 0.1501 & 0.1212 & 0.0923 & 0.1337 & 0.1545 \\
\hline SD & 0.4216 & 0.2725 & 0.4500 & 0.4675 & 0.4394 & 0.3277 & 0.4138 & 0.4335 \\
\hline Min. & -1.0008 & -1.0000 & -1.0008 & -1.0000 & -1.0008 & -1.0000 & -1.0000 & -1.0008 \\
\hline Max. & 4.0000 & 2.9409 & 4.0000 & 4.0000 & 3.9231 & 3.5802 & 3.8454 & 4.0000 \\
\hline \multicolumn{9}{|l|}{ (Size) } \\
\hline Mean & 12.3831 & 12.9620 & 12.0529 & 12.1469 & 12.6839 & 12.6537 & 12.5695 & 12.5403 \\
\hline D P. & 1.8921 & 1.8689 & 1.9365 & 1.7879 & 1.8533 & 1.8184 & 1.8379 & 1.7752 \\
\hline Min. & 3.0445 & 6.0497 & 3.3673 & 4.8828 & 6.0497 & 7.6601 & 7.1229 & 3.3322 \\
\hline Max. & 19.1138 & 18.2814 & 19.1138 & 18.1060 & 18.1330 & 18.6830 & 19.1138 & 18.5160 \\
\hline
\end{tabular}




\begin{tabular}{|c|c|c|c|c|c|c|c|c|}
\hline & \multirow{2}{*}{ Total sample } & \multicolumn{2}{|c|}{ Accruals quality } & \multicolumn{2}{|c|}{ Financial constraint } & \multicolumn{3}{|c|}{ Investment decision } \\
\hline & & High & Low & No & Yes & Efficient & Over & Under \\
\hline \multicolumn{9}{|l|}{ (AQ) } \\
\hline Mean & 0.0482 & 0.0219 & 0.0821 & 0.0481 & 0.0518 & 0.0436 & 0.0483 & 0.0495 \\
\hline D P. & 0.0317 & 0.0059 & 0.0324 & 0.0308 & 0.0343 & 0.0273 & 0.0303 & 0.0314 \\
\hline Min. & 0.0025 & 0.0025 & 0.0523 & 0.0051 & 0.0049 & 0.0049 & 0.0049 & 0.0025 \\
\hline $\begin{array}{l}\text { Max. } \\
\text { (KZ) }\end{array}$ & 0.4193 & 0.0310 & 0.4193 & 0.3127 & 0.3319 & 0.1964 & 0.2458 & 0.2654 \\
\hline Mean & 1.2652 & 1.2962 & 1.2831 & -0.1312 & 2.4604 & 1.3348 & 1.2749 & 1.3796 \\
\hline D P. & 1.4684 & 1.0830 & 1.8354 & 1.6203 & 0.7323 & 1.2797 & 1.4260 & 1.4056 \\
\hline Min. & -9.9851 & -7.2980 & -9.9851 & -9.9851 & 1.7982 & -9.3228 & -9.9851 & -9.4615 \\
\hline $\begin{array}{l}\text { Max. } \\
\text { (ROE) }\end{array}$ & 9.9615 & 7.5727 & 8.7274 & 0.9967 & 9.9615 & 7.1859 & 9.7858 & 9.9615 \\
\hline Mean & 0.0456 & 0.0762 & 0.0290 & 0.1075 & -0.0526 & 0.0519 & 0.0624 & 0.0322 \\
\hline D P. & 0.2704 & 0.1739 & 0.3727 & 0.1523 & 0.3946 & 0.2603 & 0.2553 & 0.2982 \\
\hline Min. & -1.9946 & -1.6740 & -1.9946 & -1.4213 & -1.9946 & -1.9131 & -1.9457 & -1.9946 \\
\hline Max. & 1.9802 & 1.6977 & 1.9802 & 1.4362 & 1.9802 & 1.7730 & 1.7755 & 1.9802 \\
\hline
\end{tabular}

Where Over and under refer to, respectively, the group of firms with investments in excess and the group of firms with investments below the necessary level; $I$ is the company's investment rate, measured by the change in capital stock; $K$ is the capital stock, measured by assets; $C F$ refers to cash flow, defined as the sum of amortization, depletion, and depreciation added to net income; $S$ is sales, obtained through the net operating revenues; $D$ refers to debt, measured by the current liabilities plus the non-current liabilities; $\Delta S$ is the sales growth; Size is the size of the firm, measured by the natural logarithm of total assets; $A Q$ is the proxy that was employed as a measurement of earnings quality and evaluated based on the standard deviation of accounting adjustments, the difference between cash and accruals for each company between years $\mathrm{t}-4$ and $\mathrm{t}$, according to Equation 3; $\mathrm{KZ}$ is a continuous variable representing the degree of financial constraint, according to Equation 4; and ROE is the return on equity. Note: Adapted from Carvalho, Kalatzis, and Albuquerque (2014).

It is observed that the parameter of the variable representing low earnings quality $\left((A Q)^{\prime}{ }^{\prime} t-1\right)$ is positively associated with the investment volume of financially constrained firms, firms with investment decisions that are considered efficient, and firms with overinvestment. The parameter is negative and significant for groups of non-financially constrained companies and firms with underinvestment. This result shows that low earnings quality will increase investment rates, especially for companies that already invest at higher levels than necessary (overinvestments). However, we could note a negative relationship between low earnings quality and the investment rate of underinvesting companies. That is, as the quality of their financial information decreases, the companies that underinvest or overinvest will tend to reinforce that behavior more. 
Table 4.

Investment model for firms grouped according to accruals quality, financial constraint, and investment decision efficiency

\begin{tabular}{|c|c|c|c|c|c|c|c|}
\hline & \multicolumn{2}{|c|}{ Accruals quality } & \multicolumn{2}{|c|}{ Financial constraint } & \multicolumn{3}{|c|}{ Investment decisions } \\
\hline & High & Low & Yes & No & Efficient & Over & Under \\
\hline \multirow{2}{*}{$\left(\mathrm{I} / \mathrm{K}_{\mathrm{t}-1}\right)_{\mathrm{i}, \mathrm{t}-1}$} & $-0.2088^{* * *}$ & $-0.1345^{* * *}$ & $-0.154^{* * *}$ & $-0.4265^{* * *}$ & $-0.2702^{* * *}$ & $-0.4276^{* * *}$ & $-0.333^{* * *}$ \\
\hline & $(0.0006)$ & $(0.0004)$ & $(0.0007)$ & $(0.0008)$ & $(0.0009)$ & $(0.0011)$ & $(0.0007)$ \\
\hline \multirow{2}{*}[(\mathrm{I}/\mathrm{K}_{\mathrm{t}-1})^{2}]{$_{\mathrm{i}, \mathrm{t}-1}$} & $-0.0324^{* * *}$ & $-0.0262^{* * *}$ & $-0.036^{* * *}$ & $-0.0191^{* * *}$ & $-0.0205^{* * *}$ & $-0.0479^{* * *}$ & $-0.0189^{* * *}$ \\
\hline & $(0.0004)$ & $(0.0001)$ & $(0.0002)$ & $(0.0002)$ & $(0.0001)$ & $(0.0010)$ & $(0.0003)$ \\
\hline \multirow{2}{*}{$(A Q)_{i, t-1}$} & & & $0.4358^{* * *}$ & $-0.221^{* * *}$ & $1.4223^{* * *}$ & $1.4485^{* * *}$ & $-0.6258^{* * *}$ \\
\hline & & & $(0.0107)$ & $(0.0184)$ & $(0.0311)$ & $(0.0351)$ & $(0.0134)$ \\
\hline \multirow{2}{*}{$\left(\mathrm{CF} / \mathrm{K}_{\mathrm{t}-1}\right)_{\mathrm{i}, \mathrm{t}}$} & $-0.5625^{* * *}$ & $-0.6085^{* * *}$ & $-0.6284^{* * *}$ & $0.0707^{* * *}$ & $-1.2429^{* * *}$ & $-1.2853^{* * *}$ & $-0.2775^{* * *}$ \\
\hline & $(0.0156)$ & $(0.0059)$ & $(0.0066)$ & $(0.0035)$ & $(0.0196)$ & $(0.0095)$ & $(0.0106)$ \\
\hline \multirow{2}{*}{$(b \mathrm{KZ})_{\mathrm{i}, \mathrm{t}}$} & $-0.0972^{* * *}$ & $-0.0104^{* * *}$ & & & $-0.1855^{* * *}$ & $-0.0506^{* * *}$ & $-0.0032^{* *}$ \\
\hline & $(0.0037)$ & $(0.0008)$ & & & $(0.0013)$ & $(0.0009)$ & $(0.0016)$ \\
\hline \multirow{2}{*}{$\left(S / K_{t-1}\right)_{i, t}$} & $0.0435^{* * *}$ & $0.0553^{* * *}$ & $0.0561^{* * *}$ & $0.0187^{* * *}$ & $0.0727^{* * *}$ & $0.0218^{* * *}$ & $-0.0134^{* * *}$ \\
\hline & $(0.0004)$ & $(0.0001)$ & $(0.0001)$ & $(0.0001)$ & $(0.0002)$ & $(0.0003)$ & $(0.0002)$ \\
\hline \multirow{2}{*}{$\left(\mathrm{D} / \mathrm{K}_{\mathrm{t}-1}\right)_{\mathrm{i}, \mathrm{t}}$} & $0.1504^{* * *}$ & $0.1721^{* * *}$ & $0.1667^{* * *}$ & $0.0673^{* * *}$ & $0.1371^{* * *}$ & $0.0997^{* * *}$ & $0.1517^{* * *}$ \\
\hline & $(0.0007)$ & $(0.0005)$ & $(0.0004)$ & $(0.0001)$ & $(0.0005)$ & $(0.0009)$ & $(0.0004)$ \\
\hline \multirow{2}{*}{$(\text { Size })_{\mathrm{i}, \mathrm{t}}$} & $0.2268^{* * *}$ & $0.203^{* * *}$ & $0.2332^{* * *}$ & $0.4512^{* * *}$ & $0.0778^{* * *}$ & $0.8986^{* * *}$ & $0.2684^{* * *}$ \\
\hline & $(0.0022)$ & $(0.0008)$ & $(0.0011)$ & $(0.0010)$ & $(0.0030)$ & $(0.0017)$ & $(0.0012)$ \\
\hline \multirow{2}{*}{$(\Delta S)_{\mathrm{i}, \mathrm{t}}$} & $0.1776^{* * *}$ & $0.1171^{* * *}$ & $0.1281^{* * *}$ & $0.2581^{* * *}$ & $0.2028^{* * *}$ & $0.1061^{* * *}$ & $0.1706^{* * *}$ \\
\hline & $(0.0014)$ & $(0.0005)$ & $(0.0006)$ & $(0.0007)$ & $(0.0011)$ & $(0.0016)$ & $(0.0009)$ \\
\hline \multirow{2}{*}{$(\Delta S)_{\mathrm{i}, t-1}$} & $-0.0076^{* * *}$ & $-0.0112^{* * *}$ & $-0.0335^{* * *}$ & $0.1391^{* * *}$ & $0.0489^{* * *}$ & $0.0887^{* * *}$ & $0.0682^{* * *}$ \\
\hline & $(0.0014)$ & $(0.0003)$ & $(0.0004)$ & $(0.0007)$ & $(0.0009)$ & $(0.0012)$ & $(0.0006)$ \\
\hline \multirow{2}{*}{$\left(\left(\mathrm{CF} / \mathrm{K}_{\mathrm{t}-1}\right)^{*}(\mathrm{AQ})\right)_{\mathrm{i}, \mathrm{t}}$} & & & $0.1997^{* * *}$ & $-0.1822^{* * *}$ & $-1.9096^{* * *}$ & $-0.2437^{* * *}$ & $0.3737^{* * *}$ \\
\hline & & & $(0.0192)$ & $(0.0132)$ & $(0.0502)$ & $(0.0412)$ & $(0.0227)$ \\
\hline \multirow{2}{*}{$\left(\left(\mathrm{CF} / \mathrm{K}_{\mathrm{t}-1}\right)^{*}(\mathrm{KZ})\right)_{\mathrm{i}, \mathrm{t}}$} & $0.0677^{* * *}$ & $0.0086^{* * *}$ & & & $-0.0039^{* * *}$ & $0.0009^{*}$ & $0.0452^{* * *}$ \\
\hline & $(0.0003)$ & $(0.0001)$ & & & $(0.0003)$ & $(0.0005)$ & $(0.0002)$ \\
\hline \multirow{2}{*}{$\left(\left(\mathrm{CF} / \mathrm{K}_{\mathrm{t}-1}\right)^{*}(\mathrm{ROE})\right)_{\mathrm{i}, \mathrm{t}}$} & $0.1493^{* * *}$ & $0.0469^{* * *}$ & $-0.1036^{* * *}$ & $-0.0136^{* * *}$ & $-0.1728^{* * *}$ & 0.007 & $-0.0113^{* * *}$ \\
\hline & $(0.0091)$ & $(0.0007)$ & $(0.0009)$ & $(0.0011)$ & $(0.0031)$ & $(0.0061)$ & $(0.0014)$ \\
\hline \multirow{2}{*}{$\left(\left(\mathrm{CF} / \mathrm{K}_{\mathrm{t}-1}\right)^{*}(\text { Size })\right)_{\mathrm{i}, \mathrm{t}}$} & $0.0586^{* * *}$ & $0.0381^{* * *}$ & $0.0453^{* * *}$ & $-0.0153^{* * *}$ & $0.112^{* * *}$ & $0.0996^{* * *}$ & $0.0105^{* * *}$ \\
\hline & $(0.0014)$ & $(0.0005)$ & $(0.0005)$ & $(0.0003)$ & $(0.0015)$ & $(0.0006)$ & $(0.0008)$ \\
\hline Observations & 662 & 607 & 983 & 929 & 432 & 379 & 524 \\
\hline Sample & 278 & 268 & 330 & 301 & 251 & 238 & 282 \\
\hline \multicolumn{8}{|l|}{ Autocorrelation test } \\
\hline First-order & 0.0775 & 0.0557 & 0.0039 & 0.0785 & 0.0773 & 0.1171 & 0.0715 \\
\hline Second-order & 0.2059 & 0.2113 & 0.6735 & 0.682 & 0.8541 & 0.5351 & 0.5875 \\
\hline Sargan test & 0.9999 & 0.9999 & 0.9999 & 0.9999 & 0.9999 & 0.9999 & 0.9999 \\
\hline
\end{tabular}

Estimate performed by GMM. The estimated models are given by Equations 7, 8, and 9. The dependent variable is $\left[\left(\mathrm{I} / \mathrm{K}_{\mathrm{t}-1}\right)\right.$ $\left.{ }_{i, t}\right]$. The description of the variables is shown in Table 1 . The classification of firms as companies of high or low quality and their financial information was conducted considering the first and third terciles of Equation 3, as schematically shown in Figure 1. Standard errors are reported in parentheses. The symbols $\left({ }^{* *}\right),\left({ }^{* *}\right)$, and $\left(^{*}\right)$ indicate significance at $1 \%$, $5 \%$, and $10 \%$, respectively. Over refers to overinvestments and under to underinvestments. 
The results of this study indicate that there is empirical evidence that low earnings quality significantly affects corporate investment decisions in Latin America. These results are consistent with Healy and Palepu (2001), for whom accounting reports and financial reporting are of paramount importance for managers to effectively communicate a firm's performance to investors. Bushman and Smith (2001) added to this understanding by pointing out that the information provided by accounting is intended to facilitate the flow of scarce financial resources to direct them to the most promising investment opportunities. Carvalho, Kalatzis, and Albuquerque (2014) showed a positive relationship between low quality accounting information and the probability of inappropriate investment decisions.

Another important aspect of investment decisions is the presence or absence of available cash for investment. Jensen and Meckling (1976) pointed out that excess cash flow can be used in bad investments when managers' interests are not aligned with shareholders' objectives. For Myers and Majluf (1984), decision makers may prefer to use internal resources in investments because it would require a lower level of information to be disclosed. Thus, the relationship between the variables "cash flow relative to capital stock" $\left(\left(C F / K_{t-1}\right)_{i, t}\right)$ and investment rates was analyzed in each of the groups shown in Table 4.

The variable $\left(C F / K_{t-1}\right)$ was negatively and significantly related to the investment rates of all groups except for the group of non-financially constrained firms, whose parameter was positive. For Fazzari et al. (1988), positive investmentcash flow sensitivity can be explained by high funding costs of external resources, which is consistent with the situation of the companies in this region, where the financial market remains in its infancy. This explanation is consistent with the reality of companies from Latin America, where the market is in development; this, in turn, inhibits the availability of third-party capital for financing investments, thus increasing the dependence of investments on internally generated funds. However, increases in cash flow will lead to a reduction in investment rates for the other groupings, as shown in Table 4, where we can observe a negative coefficient for the variable $\left(C F / K_{t-1}\right)$ for all groups, excepted for the group of firms that was considered to be non-financially constrained. Cleary (2006) and Khurana (2006) stated that companies with poor financial indicators postpone investments in order to have some financial flexibility and thereby reduce the risk of needing external financing in the future. In such situations, a reduction in investment is expected, which explains the negative relationship between investment rates and cash flow $\left(C F / K_{t-1}\right)$ for the other groupings.

Hovakimian (2009) classified companies into those with high growth opportunities and low levels of liquidity and firms whose investment rates had negative cash flow sensitivity in order to investigate the determinants of investment-cash flow sensitivity and thus analyze the characteristics of the firms in each group. For the author, firms with negative cash flow sensitivity are characterized by low levels of liquidity and high growth opportunities.

Bhagat, Moyen, and Syh (2005) considered that negative investment-cash flow sensitivity is clearly contrary to the pecking order theory, which claims that internally generated funds take priority as the preferred source of investment. The authors concluded that when a reduction in the internal capacity to generate resources is verified, there will be more investment because this increase in investment is an attempt to improve the firm's future performance. Cleary, Povel, and Raith (2007) reached similar conclusions when investigating how the availability of internal resources affects investments. For the authors, companies with low levels of cash flow invest more in an attempt to generate enough revenue to meet their contractual obligations. This investment occurs because, as Bhagat, Moyen, and Syh (2005) stated, new investments are seen as strategic by decision makers, who attempt to guarantee the future performance of companies. 
Upon analyzing the financial constraint indicator variable ( $b K Z$ ), a negative and significant parameter was observed for all groups, regardless of earnings quality (high or low) or efficiency in investment decisions (efficient, over, or underinvestment). This result is consistent with the theoretical expectation, as financial constraint is considered a major problem for business growth, i.e., the negative parameter confirms that constrained firms tend to reduce investment.

In contrast, the variable "sales relative to capital stock" $\left(S / K_{t-1}\right)$ showed a positive and significant relationship with the investment rates for all groups in Table 4, except for the group of underinvesting firms. This variable represents the flow of fixed assets and can be considered a measure of firms' operating performance. The result indicates that factors other than operational performance may influence investment decisions. It therefore appears that companies that underinvest reduce investments even when sales volumes are higher than fixed assets. This trend is justified by the negative coefficient of the sales variable in relation to the volume of investments for the group of firms that underinvest.

It can be noted in Table 4 that the parameter of the variable "debt relative to capital stock" (D/ $\left.K_{t-1}\right)$ is positive and statistically significant for all analyzed groups. This positive effect on investment rates for all groups is justified by the tax benefits resulting from financial leverage. It is observed that investments by both financially constrained and non-financially constrained businesses are sensitive to debt and that constrained firms are more sensitive to this variable, showing a 0.1667 parameter against 0.0673 . This result may be due to a greater reliance on external resources for the execution of investments by companies in the constrained group.

The size variable parameter (Size) showed a positive sign for explaining the investment of companies in all groups, where the investment rates $\left(I / K_{t-1}\right)$ of overinvesting companies are most sensitive to "size" (Size). Thus, the results indicate that the bigger the firm, the greater the likelihood of an increase in investment rates, which may be associated with economies of scale and the fact that larger firms have easier access to capital sources.

According to Brush, Bromiley, and Margaretha (2000), sales growth is seen and disclosed to the market as a key aspect of the firms' future profitability. However, the authors consider that in many situations, sales growth benefits managers more than shareholders. In line with this view, Dechow, Ge, and Schrand (2010) argued that shareholders of firms in the growth phase are more tolerant of inappropriate attitudes by managers. Thus, with sales growth, there will be incentives for new investments, even if these incentives are not appropriate. Such results involving sales or their growth are consistent with Fazzari's (1993) understanding, according to which there is evidence that interest rates and the cost of capital play a small and uncertain role in determining investments compared to the financial impact of sales growth. According to Brush, Bromiley, and Hendrickx (2000), sales growth is one of the main features observed for evaluating and promoting executives. The authors also pointed out that empirical research has found that sales growth is the most frequently cited common aim by senior managers.

The interaction variables in the model, $\left(\left(C F / K_{t-1}\right) *(A Q)\right),\left(\left(C F / K_{t-1}\right) *(K Z)\right), \quad\left(\left(C F / K_{t-}\right.\right.$ $\left.\left.{ }_{1}\right)^{*}(R O E)\right)$, and $\left(\left(C F / K_{t-1}\right) *(S i z e)\right)$, aimed to measure investment-cash flow sensitivity, considering specific characteristics of the firms for this purpose.

The interaction variable $\left(\left(C F / K_{t-1}\right)^{*}(A Q)\right)$ aimed to measure the impact of financial information quality on investment-cash flow sensitivity. We can note in Table 4 that firms classified as financially constrained presented a positive and significant parameter for this variable. It therefore appears that deterioration in earnings quality coupled with increased cash flow will generate greater investment for financially constrained firms. That is, low quality accounting 
adjustments (accruals) increase investment-cash flow sensitivity for financially constrained Latin American firms. These results are consistent with those presented by Biddle, Hilary, and Verdi (2009), who pointed out that high quality accounting adjustments reduce investment-cash flow sensitivity. However, it is worth noting that the group of non-financially constrained firms, which showed low earnings quality, presented a negative parameter for this variable.

Investment-cash flow sensitivity is explained by different theoretical views. One is based on the proposition by Fazzari et al. (1988), for whom investment-cash flow sensitivity reflects the high cost of debt compared to the cost of internal resources, which can be caused by asymmetric information and agency problems (Hovakimian, 2009). Another theoretical perspective, according to Hovakimian (2009), suggests that investment-cash flow sensitivity is due to financial constraint.

In addition, the interaction between "cash flow relative to capital stock" and "low earnings quality" ((CF/K $\left.\left.K_{t-1}\right)^{*}(A Q)\right)$ for the firms grouped according to their efficiency in investment decisions aimed to investigate whether worse earnings quality, represented by higher values of the $A Q$ variable, results in increased investmentcash flow sensitivity. Investments by firms in the efficient investment decision group and those in the overinvesting group were significant and negatively related to this interaction variable, and companies with underinvestment showed a positive parameter.

The interaction variable between cash flow and financial constraint $\left(\left(C F / K_{t-1}\right)^{*}(K Z)\right)$ aimed to evaluate the effect of financial constraint on investment-cash flow sensitivity. The positive sign associated with this variable, together with its significance for the groupings according to low or high quality earnings, shows that financial constraint increases investment-cash flow sensitivity, regardless of the quality level of the financial information. However, it is possible to note that the firms with high-quality earnings and a higher degree of financial constraint (higher $K Z$ values) presented greater investment-cash flow sensitivity. This result is demonstrated by the coefficient values 0.0677 for high-quality-earnings companies and only 0.0086 for low-qualityearnings firms. Thus, high-quality financial information, coupled with a situation of financial constraint, apparently increases investment-cash flow sensitivity. As for the groups sorted according to investment decisions, the companies with investment decisions considered to be effective, as well as overinvesting entities, showed a parameter close to zero for this variable (-0.0039 and 0.0009). For the group of underinvesting companies, the parameter was positive and significant (0.0452).

The interaction between cash flow and performance was obtained through the construction of the interaction variable between ROE and cash flow $\left(\left(C F / K_{t-1}\right) *(R O E)\right)$. The results presented in Table 4 suggest that higher profitability increases the investment-cash flow sensitivity of firms with high and low profits. That is, an improvement in firms' operating performance, as measured by the $R O E$, will stimulate investments through the use of surplus cash resources, regardless of earnings quality.

$R O E$ is seen as one of the leading and most popular accounting measures of firm performance (Du Toit \& De Wet, 2007). It is often established as a metric to evaluate the performance of corporate governance, as it can be broken down into net margin, level of asset utilization (turnover), and debt. Thus, positive performance evaluated by that measure can be used to justify new investments. On the other hand, this variable presented negative coefficients for firms classified as financially constrained, nonfinancially constrained, efficient in investment decisions, and with underinvestment. For the group of financially constrained firms or firms with investment decisions considered to be efficient, it was noted that profitability more effectively reduces the volume of investments, as this group showed higher parameters for this variable (-0.1036 and -0.1728). In turn, for non- 
financially constrained firms - that is, companies that in theory have a greater volume of resources - profitability will also reduce investment-cash flow sensitivity, but to a lesser extent, as shown by the parameter of-0.0136. It appears, however, that the parameter for overinvesting firms is not significant. Thus, firms with efficient investment decisions that have cash flow available and that show high profitability tend to invest less $(-0.1728)$. The same occurs, although with a lower sensitivity (-0.0113), with underinvesting firms. Consequently, superior performance, i.e., higher $R O E$ values, will decrease investmentcash flow sensitivity in the effective decisions and underinvestment group. Thus, investment dependence on internally generated funds is reduced for these groups. It can be inferred that an increase in profitability may result in an increase in the use of internally generated funds in a more efficient manner.

The cash flow and size interaction variable $\left(\left(C F / K_{t-1}\right)^{*}(\right.$ Size $\left.)\right)$ was included in the models in order to verify whether the size of the company reduces investment-cash flow sensitivity. Size is measured by means of the natural logarithm of total assets. Kadapakkama, Kumarb, and Riddickb (1998) stated that because big companies have lower transaction costs, are less susceptible to asymmetric information, and involve greater participation by large institutional shareholders, they are expected to have lower investment-cash flow sensitivity.

The results indicate that the investments of larger companies with higher quality earnings are affected by the availability of internal resources (significant and positive parameters). The same behavior is observed for the coefficient of firms with low quality earnings. This result is in line with the findings by Vogt (1994) and Kadapakkam, Kumar, and Leigh (1998), who verified that, compared to investments by small businesses, investments by large firms are more sensitive to internal funds.

However, Kadapakkam, Kumar, and Leigh (1998) highlighted that this greater sensitivity should be analyzed with caution because larger firms have easier access to external sources of funds than smaller firms, and therefore, larger firms should be less sensitive to internally generated funds. The authors questioned the validity of investment-cash flow sensitivity as a proxy for financial constraint. They suggested that smaller companies' lower investment-cash flow sensitivity may be due to the greater competition to which they are exposed, due to them having few products and a low market share, which forces them to invest, regardless of whether they have internal resources. In addition, the authors point out that the cost of third-party capital and transaction costs may be high, thus discouraging its use. In order to obtain such resources, large firms might have to provide more information to the market.

Considering these aspects and the fact that large firms have greater investment flexibility, such firms may wait for internal resources to be available in order to make investments, which explains their greater investment-cash flow sensitivity.

This understanding is supported by the pecking order theory, according to which transaction costs (the cost of issuing new bonds and agency costs) resulting from the acquisition of debt outweigh the benefits in some cases. Therefore, firms prioritize internally generated resources, followed by financing through debt, and, finally, via equity.

Through the pecking order theory approach, decision makers choose to finance investments using sources of capital that are less sensitive to information. The managers or controlling shareholders of corporations therefore tend to opt for internally generated resources, which is not necessarily due to the difficult access to external sources of capital but mainly due to their interest in refraining from publishing data that may increase the monitoring and control of their management.

Thus, retained earnings are chosen as the preferred source of funds, not because they present lower funding costs but mainly because 
this source requires lower levels of information, which explains the greater investment-cash flow sensitivity of large firms with low information quality. This variable showed a significant and positive parameter for financially constrained firms and a negative parameter for the group of firms classified as non-financially constrained. Thus, it is possible to note that size increases investment-cash flow sensitivity for financially constrained firms.

According to Kadapakkam, Kumar, and Riddick (1998), large companies have greater agency problems and more flexibility to decide when to invest. Therefore, subject to the availability of free cash flow, managers have the flexibility to decide on which projects to invest in and when.

The results presented are evidence that financially constrained firms are more sensitive to cash flow, especially when these firms have greater information asymmetry (low earnings quality). Regarding the grouping based on efficiency of investment decisions, the results were significant and positive for all groups, as shown in Table 4. Similar results were obtained by Aldrighi and Bisinha (2010), who observed a positive coefficient for the interaction variables of cash flow and size regarding investment rates by Brazilian companies. For Kadapakkam, Kumar, and Leigh (1998), investments by large companies are more sensitive to internal funds than those by small firms, as large companies are more susceptible to earnings management.

\section{Conclusion}

The basic premise of this study was the hypothesis that better financial information contributes to making better investment decisions, as it reduces the level of information asymmetry. This finding can be explained by the fact that high-quality financial information facilitates the process of monitoring managers because, by reducing existing asymmetries, it inhibits opportunistic behavior, ensuring the rights of both shareholders and creditors.
By grouping the sample companies from seven Latin American countries according to high quality and low quality earnings and by analyzing the determinants of investment for each cluster, we can note that investment rates are positively related to the movements of fixed assets, debt, sales growth, and size. In turn, increases in cash flow will lead to reductions in investment rates.

In addition, through the interaction variables, we observed that companies that are classified as having high earnings quality and presenting a high degree of financial constraint, which are also large companies and present a greater return on shareholders' equity, are more sensitive to cash flow. Given the above, we can conclude that high or low earnings quality affects the determinants of investment of Latin American companies and that the investmentcash flow sensitivity of these entities is influenced by accruals quality.

When sorting the companies by their level of efficiency in investment decision-making and analyzing the determinants of investment, apart from the proxy for earnings quality $(A Q)$, the variables representing firm growth and interaction variables were also included. One factor that could be a limitation of this paper was the proxies that were selected to represent financial constraint and accruals quality. Therefore, future studies could use different proxies or methodologies.

The results of this study indicate that low earnings quality positively affects the rate of investment of companies with investment decisions that are considered to be effective. In addition, upon dividing the group of firms considered as making inefficient decisions into overinvesting and underinvesting firms, it was found that investments by overinvesting firms are positively associated with low earnings quality. In contrast, investments by companies in the underinvestment group are negatively affected by low earnings quality.

Thus, we can conclude that companies investing more than needed will invest even more as the quality of their financial information 
deteriorates. However, companies that have failed to invest in economically attractive projects tend to accentuate this behavior as the quality of their financial information worsens. It follows that low earnings quality accounts for deterioration in the efficiency of the investment decisions of the analyzed firms, highlighting the possibility of agency problems.

By sorting the companies into financially constrained and non-financially constrained firms, it was found that the investment rates of both classes of firms are associated with low earnings quality and that this, in turn, is positively related to investment rates for constrained firms and negatively associated with them in the case of non-financially restricted businesses. Another important point is the verification of the greater investment-cash flow sensitivity of financially constrained companies when they present poor earnings quality. It therefore follows that investments by financially constrained Latin American businesses and their investment-cash flow sensitivity are impacted by earnings quality.

As a general conclusion, we highlight the empirical evidence regarding the importance of accounting information for investment decisionmaking. This study provides additional evidence that high-quality accounting information could contribute to a reduction of asymmetric information between stakeholders and discourage managers' discretionary behavior. Thus, as a practical implication of the study, we highlight the need to adopt a mechanism to improve the quality of the financial information disclosed by firms.

\section{References}

Aboody, D., Hughes, J., \& Liu, J. (2005). Earnings quality, insider trading, and cost of capital. Journal of Accounting Research, 43(5), 651673. Retrieved from ISI>://000233256300001

Albanez, T., \& Valle, M. R. (2009). Impacts of information asymmetry on the capital structure of Brazilian publicly traded firms. Revista Contabilidade \& Finanças, 20(51), 6-27.
Aldrighi, D. M., \& Bisinha, R. (2010). Restrição financeira em empresas com açóes negociadas na Bovespa. Revista Brasileira de Economia, 64(1). Retrieved from http://dx.doi.org/10.1590/ S0034-71402010000100002

Almeida, H., \& Campello, M. (2007). Financial constraints, asset tangibility, and corporate investment. Review of Financial Studies, 20I(5), 1429-1460.

Anderson, R. C., Mansi, S. A., \& Reeb, D. M. (2004). Board characteristics, accounting report integrity, and the cost of debt. Journal of Accounting \& Economics, 37(3), 315-342. Retrieved from ISI >://000224231400002

Arellano, M., \& Bond, S. (1991). Some tests of specification for panel data: Monte Carlo evidence and an application to employment equations. The review of economic studies, 58(2), 277-297.

Arellano, M., \& Bover, O. (1995). Another look at the instrumental variable estimation of errorcomponents models. Journal of econometrics, 68(1), 29-51.

Ball, R., \& Brown, P. (1968). Empirical evaluation of accounting income numbers. Journal of Accounting Research, 6(2), 159-178. Retrieved from ISI>://WOS:A1968ZJ98600001

Bassetto, C. F., \& Kalatzis, A. E. G. (2011). Financial distress, financial constraint and investment decision: Evidence from Brazil. Economic Modelling, 28(1-2), 264-271. Retrieved from www.scopus.com

Bhagat, S., Moyen, N. T., \& Suh, I. (2005). Investment and internal funds of distressed firms. Journal of Corporate Finance, 11(3), 449-472.

Biddle, G. C., Hilary, G., \& Verdi, R. S. (2009). How does financial reporting quality relate to investment efficiency? Journal of Accounting and Economics, 48(2-3), 112-131. Retrieved from http://www.scopus.com/inward/record.url?eid=2s2.0-70350404649\&partnerID $=40 \& \mathrm{md} 5=$ f5503 $83754 \mathrm{eb} 6422 \mathrm{a} 2 \mathrm{e} 56 \mathrm{bba} 9761 \mathrm{f0} 2 \mathrm{f}$ 
Blundell, R., \& Bond, S. (1998). Initial conditions and moment restrictions in dynamic panel data models. Journal of econometrics, 87(1), 115-143.

Bolton, P., \& Freixas, X. (2000). Equity, bonds, and bank debt: Capital structure and financial market equilibrium under asymmetric information. The Journal of Political Economy, 108, (2), 324-351. Retrieved from http://www.jstor. org/stable/10.1086/262121

Botosan, C. (1997). Disclosure level and the cost of equity capital. The Accounting Review, 72(3), 323-349. Retrieved from http://www.jstor.org/ stable/248475

Branco, M. C. (2006). Uma abordagem institucionalista da contabilidade. Revista Contabilidade \& Finanças, 2006, 17(42), 104112. Retrieved from http://dx.doi.org/10.1590/ S1519-70772006000300009

Brush, T. H., Bromiley, P., \& Hendrickx, M. (2000). The free cash flow hypothesis for sales growth and firm performance. Strategic Management Journal, 21, 455-471. Retrieved from http://onlinelibrary.wiley.com/doi/10.1002/ (SICI) 1097-0266(200004)21:4\%3C455::AIDSMJ83\%3E3.0.CO;2-P/pdf

Bushman, R., Chen, Q., Engel, E., \& Smith, A. (2004). Financial accounting information, organizational complexity and corporate governance systems. Journal of Accounting and Economics, 37(2), 167-201.

Bushman, R., \& Smith, A. J. (2001). Financial accounting information and corporate governance. Journal of accounting and Economics, 32(1-3), $237-$ 333.

Carvalho, F. L., Kalatzis, A. E. G., \& Albuquerque, A. A. (2014). The relationship between earnings quality and the probability of efficient investment decisions in Latin America. Latin American Journal of Management for Sustainable Development, 1(23), 229-250.
Chan, C. Y., Chou, D. W., Lin, J. R., \& Liu, F. Y. (2016). The role of corporate governance in forecasting bankruptcy: Pre-and post-SOX enactment. The North American Journal of Economics and Finance, 35, 166-188.

Cleary, S. (2006). International corporate investment and the relationship between financial constraint measures. Journal of Banking and Finance, 3O(5), 1559-150.

Cleary, S., Povel, P., \& Raith, M. (2007). The U-shaped investment curve: Theory and evidence. Journal of Financial and Quantitative Analysis, 42(1), 1-39. Retrieved from ISI >:// WOS:000244843900001

Core, J. E., Guay, W. R., \& Verdi, R. (2008). Is accruals quality a priced risk factor? Journal of Accounting and Economics, 46(1), 2-22.

Dechow, P.; Ge, W.; Schrand, C. (2010). Understanding earnings quality: A review of the proxies, their determinants and their consequences. Journal of Accounting and Economics, 50(2/3), 344401. Retrieved from http://www.scopus.com/ inward/record.url?eid=2-s2.0-77953887285\&pa rtnerID $=408 \mathrm{md} 5=9 \mathrm{e} 9 \mathrm{a} 5347 \mathrm{c} 1 \mathrm{ca} 75 \mathrm{fcc} 480 \mathrm{a} 767$ 98 ecc0a7

Dechow, P. M., \& Dichev, I. D. (2002). The Quality of accruals and earnings: the role of accrual estimation errors. Accounting Review, 77(Suppl.), 35-59. Retrieved from http://www. scopus.com/inward/record.url?eid=2-s2.0$0036997124 \&$ partnerID $=40 \& \mathrm{md} 5=1611852 \mathrm{a}$ b60729784f9e4d23bf97a6fa

Demski, J. S. (1998). Performance measure manipulation*. Contemporary Accounting Research, 15(3), 261-285. Retrieved from http://dx.doi. org/10.1111/j.1911-3846.1998.tb00560.x

Du Toit; E.; \& De Wet, J. (2007). Return on equity: A popular, but flawed measure of corporate financial performance. South African Journal of 
Business Management, 38(1), 59-69. Retrieved from SSRN: http://ssrn.com/abstract $=1656329$

Durand, D. (1952). Cost of debt and equity funds for business: Trends and problems of measurement. In Conference on Research on Business Finance. Anais... New York: National Bureau of Economic Research, 1982, p.215-261.

Easley, D., Hvidkjaer, S., \& O’hara, M. (2002). Is Information risk a determinant of asset returns? Journal of Finance, 57(5), 2185-2221. Retrieved from ISI >://000178849700012

Easley, D., \& O'hara, M. (2004). Information and the cost of capital. Journal of Finance, 59(4), 15531583. Retrieved from ISI>://000223171800004

Eng, L. L., \& Vichitsarawong, T. (2017). Usefulness of Accounting Estimates: A tale of two countries (China and India). Journal of Accounting, Auditing \& Finance, 32(1), 123-135.

Fazzari, S. M. (1993). The Investment-finance link: Investment and U.S. fiscal policy in the 1990s. SSRN eLibrary. Retrieved from http://ssrn. $\mathrm{com} /$ paper $=138750$

Fazzari, S. M., Hubbard, R. G., Petersen, B. C., Blinder, A. S., \& Poterba, J. M. (1988). Financing constraints and corporate investment. Brookings Papers on Economic Activity, 1988(1), 141-206. Retrieved from http://www.jstor.org/ stable/2534426

Flannery, M.J. (1986). Asymmetric information and risky debt maturity choice. Journal of Finance, 41(1), 19-37. Retrieved from ISI $>$ :// WOS:A1986A294000002

Francis, J., LaFond, R., Olsson, P. M., \& Schipper, K. (2004). Costs of equity and earnings attributes. Accounting Review, 79(4), 967-1010. Retrieved from ISI >://000224779400005

Francis, J., LaFond, R., Olsson, P. M., \& Schipper, K. (2005). The Market pricing of accruals quality. Journal of Accounting and Economics, 39(2), 295 -
327. Retrieved from http://www.scopus.com/ inward/record.url?eid=2-s2.0-8744303835\&pa rtnerID $=40 \& \mathrm{md} 5=0 \mathrm{aa} 05 \mathrm{c} 2 \mathrm{e} 7 \mathrm{ab} 71318903 \mathrm{a} 18$ 2908868b49

García-Teruel, P. J., Martínez-Solano, P., \& Sánchez-Ballesta, J. P. (2009). Accruals quality and corporate cash holdings. Accounting \& Finance, 49(1), 95-115. Retrieved from http://dx.doi. org/10.1111/j.1467-629X.2008.00276.x

Healy, P. M., \& Palepu, K. G. (2001). Information asymmetry, corporate disclosure, and the capital markets: A review of the empirical disclosure literature. Journal of accounting and economics, 31(1-3), 405-440.

Hendriksen, E. S.; \& Van Breda, M. F. (1999). Teoria da contabilidade. São Paulo: Atlas.

Hribar, P., Melessa, S. J., Small, R. C., \& Wilde, J. H. (2017). Does managerial sentiment affect accrual estimates? Evidence from the banking industry. Journal of Accounting and Economics, 63(1), 26-50.

Hovakimian, G. (2009). Determinants of investment cash flow sensitivity. Financial management, 38(1), 161-183.

Hovakimian, G. T.. (2006). Corporate investment with financial constraints: Sensitivity of investment to funds from voluntary asset sales. Journal of Money, Credit and Banking, 38(2), 357-374.

Jensen, M. C., \& Meckling, W. H. (1976). Theory of firm - managerial behavior, agency costs and ownership structure. Journal of Financial Economics, 3(4), 305-360. Retrieved from ISI $>$ :// WOS:A1976CJ65000001

Kadapakkam, P. R., Kumar, P. C., \& Leigh A. R. (1998). The impact of cash flows and firm size on investment: The international evidence. Journal of Banking \& Finance, 22(3), 293-320. Retrieved from http://www.sciencedirect.com/ science/article/pii/S0378426697000599

Kammler, E. L., \& Alves, T. W. (2005). Análise da capacidade de explicação dos investimentos 
das empresas brasileiras de capital aberto através do modelo do acelerador. Revista Contabilidade \& Finanças, 16(39), 81-92.

Kaplan, S. N., \& Zingales, L. (1997). Do Investment cash-flow sensitivities provide useful measures of financing constraints? Quarterly Journal of Economics, 112(1), 169-215.

Khurana, I., Martin, X., \& Pereira, R. (2006). Financial development and the cash flow sensitivity of cash. Journal of Financial and Quantitative Analysis, 41(4), 77-07.

Kim, J. B. (2016). Accounting flexibility and managers' forecast behavior prior to seasoned equity offerings. Review of Accounting Studies, 21(4), 1361-1400.

Kirschenheiter, M., \& Melumad, N. D. (2002). Can "big bath" and earnings smoothing co-exist as equilibrium financial reporting strategies? Journal of Accounting Research, 40(3), 761-796. Retrieved from http://www.scopus.com/inward/record. url? eid=2-s2.0-0036017578\&partnerID $=40 \& \mathrm{~m}$ d5 $=43$ bfd 86 feaadbde70077bd37ae6d7896

Lamont, O., Polk, C., \& Saa-Requejo, J. (2001). Financial constraints and stock returns. Review of Financial Studies, 14(2), 529-554. Retrieved from http://rfs.oxfordjournals.org/content/14/2/529. abstract

Li, Q., \& Wang, T. (2010). Financial reporting quality and corporate investment efficiency: Chinese experience. Nankai Business Review, 1(2), 197-213.

Lopes, A. B. (2001). A Relevância da informação contábil para o mercado de capitais: $O$ modelo de Ohlson aplicado à BOVESPA (Doctoral Thesis). Faculdade de Economia Administração e Contabilidade, Universidade de São Paulo, São Paulo, SP, Brasil.

Mcnichols, M. F. (2002). Discussion of the quality of accruals and earnings: The role of accrual estimation errors. Accounting Review, 77, 61-69. Retrieved from ISI>://000180553800004
Modigliani, F., \& Miller, M. H. (1958). The Cost of capital, corporation finance and the theory of investment. The American Economic Review, 48(3), 261-297.

Modigliani, F., \& Miller, M. H. (1963). Corporate income taxes and the cost of capital: A correction. The American Economic Review, 53(3), 433-443.

Myers, S. C. (1984). Capital structure puzzle. Journal of Finance, 39(3), 575-592.

Myers, S. C., \& Majluf, N. S. (1984). Corporate financing and investment decisions when firms have information that investors do not have* 1 . Journal of Financial Economics, 13(2), 187-221.

Niu, F. F. (2006). Corporate governance and the quality of accounting earnings: A Canadian perspective. International Journal of Managerial Finance, 2(4), 302-327.

Penman, S. H., \& Zhang, X. J. (2002). Accounting conservatism, the quality of earnings, and stock returns. Accounting Review, 77(2), 237-264. Retrieved from ISI>://000175212500001

Richardson, S. (2006). Over-investment of free cash flow. Review of Accounting Studies, 11(2/3), 159189. Retrieved from ISI >://000239501500002

Richardson, S. A., Sloan, R. G., Soliman, M. T., \& Irem, T. (2005). Accrual reliability, earnings persistence and stock prices. Journal of Accounting and Economics, 39(3), 437-485. Retrieved from http://www.scopus.com/inward/record.url?eid=2s2.0-23944483675\&partnerID $=40 \& \mathrm{md} 5=62 \mathrm{ba}$ 1012aa04bc092bdfe3715bd00120

Roodman, D. (2009). A note on the theme of too many instruments. Oxford Bulletin of Economics and statistics, 71(1), 135-158.

Roosenboom, P., Van Der Goot, T., \& Mertens, G. (2003). Earnings management and initial public offerings: Evidence from the Netherlands. The International Journal of Accounting, 38(3), 243- 
266. Retrieved from http://www.sciencedirect. com/science/article/B6W4P-4906VMC-3/2/ c9f42f1936d8140d3a4b1ae17a1c32fa

Shleifer, A., \& Vishny, R. W. (1997). A Survey of corporate governance. Journal of Finance, 52(2), 737-783. Retrieved from ISI $>$ :// A1997XA18900012

Sloan, R. (1996). Do stock prices fully reflect information in accruals and cash flows about future earnings? The Accounting Review, 71(3), 289-315. Retrieved from http://www.jstor.org/ stable/248290

Sorensen, D. P., \& Miller, S. E. (2017). Financial accounting scandals and the reform of corporate governance in the United States and in Italy.
Corporate Governance: The International Journal of Business in Society, 17(1), 77-88.

StataCorp. (2009). Stata Statistical Software: Release 9. College Station, TX: StataCorp LP.

Verdi, R. S. (2006). Financial reporting quality and investment efficiency. SSRN eLibrary. Retrieved from http://papers.ssrn.com/sol3/ papers.cfm?abstract_id=930922

Vogt, S. C. (1994). The Cash flow/investment relationship: Evidence from US manufacturing firms. Financial Management, 23(2), 3-20.

Whited, T. M. (1992). Debt, liquidity constraints, and corporate investment: Evidence from panel data. The Journal of Finance, 47(4), 1425-1460.

\section{Notes:}

${ }^{1}$ Article derived from the doctoral thesis: "Qualidade das informaçôes contábeis, restrição financeira e decisóes de investimento: evidências para a América Latina” Carvalho, F. L., Escola de Engenharia de São Carlos, Universidade de São Paulo, São Carlos, 2012.

\section{Supporting Agencies:}

Coordination for the Improvement of Higher Education Personnel (CAPES)

\section{About the Authors:}

1. Flávio Leonel de Carvalho, Doctor of Science, University of São Paulo, São Paulo, Brazil.

E-mail: flavio@ufscar.br

ORCID

(iD)0000-0002-8488-9382

2. Aquiles Elie Guimarães Kalatzis, Doctor in Economics, University of São Paulo, São Paulo, Brazil. Email: aquiles@sc.usp.br

ORCID

(D)0000-0001-8534-3165

\section{Contribution of each author}

\begin{tabular}{lcc}
\hline Contribution & Flávio Leonel de Carvalho & Aquiles Elie Guimaráes Kalatzis \\
\hline 1. Definition of research problem & $\sqrt{ }$ & $\sqrt{ }$ \\
2. Development of hypotheses or research questions (empirical studies) & $\sqrt{ }$ & $\sqrt{ }$ \\
3. Development of theoretical propositions (theoretical work) & $\sqrt{ }$ & $\sqrt{ }$ \\
4. Theoretical foundation/ Literature review & $\sqrt{ }$ \\
5. Definition of methodological procedures & $\sqrt{ }$ \\
6. Data collection & $\sqrt{ }$ \\
7. Statistical analysis & $\sqrt{ }$ & $\sqrt{ }$ \\
8. Analysis and interpretation of data & $\sqrt{ }$ \\
9. Critical revision of the manuscript & $\sqrt{ }$ \\
10. Manuscript writing & $\sqrt{ }$ & $\sqrt{ }$ \\
\hline
\end{tabular}

